\title{
Near-visible light generation of a quinone methide from 3-hydroxymethyl-2-anthrol
}

Đani Škalamera, ${ }^{\dagger}$ Kata Mlinarić-Majerski, ${ }^{\dagger}$ Irena Martin-Kleiner, ${ }^{\ddagger}$ Marijeta Kralj, ${ }^{\ddagger}$ Peter Wan,${ }^{\S}$ Nikola Basarić*†

${ }^{\dagger}$ Department of Organic Chemistry and Biochemistry, Ruđer Bošković Institute, Bijenička cesta 54, 10000 Zagreb, Croatia. Fax: + 38514680 195; Tel: +385 14561 141;

E-mail: nbasaric@irb.hr

‡ Department of Molecular Medicine, Ruđer Bošković Institute, Bijenička cesta 54, 10000 Zagreb, Croatia.

$\S$ Department of Chemistry, University of Victoria, Box 3065 Stn CSC, Victoria BC, V8W 3V6, Canada

\section{Graphical abstract:}<smiles>Oc1cc2cc3ccccc3cc2cc1C(O)(c1ccccc1)c1ccccc1</smiles><smiles>FC(F)(F)OCc1ccccc1</smiles><smiles></smiles><smiles>NC(c1ccccc1)(c1ccccc1)c1cc2cc3ccccc3cc2cc1O</smiles>

9

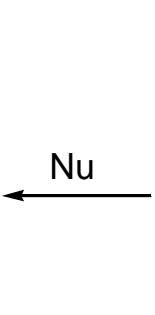<smiles></smiles> 
Abstract: Excitation of 2-hydroxy-3-(diphenylhydroxymethyl)anthracene (7) to $\mathrm{S}_{1}$ initiates photodehydration giving the corresponding quinone methide (QM) that was detected by laser flash photolysis (LFP) in 2,2,2-trifluoroethanol, TFE ( $\lambda=580 \mathrm{~nm}, \tau=690 \pm 10 \mathrm{~ns})$. The QM decays by protonation, giving cation $(\lambda=520 \mathrm{~nm}, \tau=84 \pm 3 \mu \mathrm{s})$ which subsequently reacts with nucleophiles. The rate constants in the reactions with nucleophiles were determined by LFP, whereas the adducts were isolated via preparative photolyses. The photogeneration of QMs in the anthrol series is important for potential use in biological systems since the chromophore absorbs at wavelengths $>400 \mathrm{~nm}$. Antiproliferative investigations conducted with 2-anthrol derivative 7 on three human cancer cell lines showed higher activity for irradiated cells.

Key Words: antiproliferative activity, laser flash photolysis, anthrols, photodehydration, proton transfer, quinone methides

\section{Introduction}

Quinone methides (QM) are common reactive intermediates in chemistry and in the photochemistry of phenols, attracting much attention recently owing to their biological activity. ${ }^{1}$ Although the partial zwitterionic character of QMs makes them both electrophilic and nucleophilic, their reactivity with nucleophiles is especially important in biological systems. It has been demonstrated that QMs react with amino acids ${ }^{2}$ and proteins, ${ }^{3}$ and inhibits the action of some enzymes. ${ }^{4}$ Moreover, QMs also react with nucleotides ${ }^{5}$ inducing alkylation and the crosslinking of DNA. ${ }^{6}$ The ability of QMs to cross-link DNA renders them as potential anticancer therapeutics. ${ }^{7}$ Some antineoplastic agents such as mitomycin $^{8}$ base their antiproliferative action on the metabolic formation of QMs that alkylate DNA. Moreover, some classes of anthracyclines 
such as daunomycin, that base their action on DNA cross-linking, also metabolically form QMs. ${ }^{9}$ However, later it was shown that QMs are not responsible reagents that cross-link DNA, but it probably involves metabolic formation of formaldehyde. ${ }^{10}$

QMs can be formed under mild conditions in photochemical reactions of suitably substituted phenols, such as photodehydroxylation of hydroxybenzylphenols, ${ }^{11}$ photoelimination of acetic acid, ${ }^{12}$ amines, ${ }^{13}$ or ammonium salts. ${ }^{2 b}$ Photodehydration has also been reported in the larger chromophoric systems such as suitably substituted phenylphenols ${ }^{14}$ and naphthols. ${ }^{15}$ Popik et al . studied photodehydration of naphthol $\mathbf{1}$ which gave benzoxete intermediate $\mathbf{2}$ that subsequently underwent ring opening to QM 3 (eq.1). ${ }^{16}$ The photogeneration of naphthalene QMs was later applied to photo-caging ${ }^{17}$ and for surface modification and photolithography. ${ }^{18}$

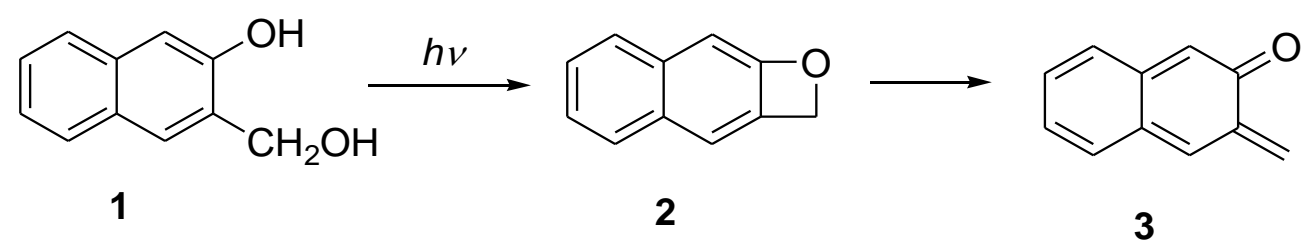

We became interested in the photochemical formation of sterically congested QMs that have potential biological applicability. ${ }^{19}$ Photo-cytotoxicity was investigated on three human cancer lines. Photo-induced antiproliferative activity was reported for naphthol, ${ }^{15 b} 1,1$ '-bi-2-naphthol $(\mathrm{BINOL})^{20}$ and naphthalene diimide QM derivatives. ${ }^{21}$ For ultimate application in vivo it is essential to develop systems that can photogenerate QMs when excited with the light of longer wavelengths (> $350 \mathrm{~nm}$ ). However, the photogeneration of QMs by photodehydration reaction in 2-anthrols or larger chromophoric systems has never been reported. ${ }^{9}$ Herein, we report the first example of photochemical QM formation (via dehydration) in an anthrol derivative 7. The photoreactivity was studied by preparative irradiations, fluorescence measurements, and by laser 
flash photolysis (LFP). Antiproliferative investigation was performed on three human cancer cell lines with and without irradiation.

\section{Results and Discussion}

Synthesis of the new anthrol 7 was accomplished in 4 steps, starting from the commercially available 2-aminoanthraquinone which was converted to 2-hydroxyanthraquinone (4) via a known procedure. ${ }^{22}$ Bromination of 4 afforded 3-bromo derivative 5 (40\%), and 1,3-dibromo derivative (38\%) which was separated from 5 by a column chromatography (Scheme 1). Subsequent reduction of 5 gave 2-bromo-3-anthrol (6) in $80 \%$ yield and a small amount of 2anthrol (8) due to undesired concomitant debromination. Lithiation with an excess of BuLi and quenching with benzophenone furnished 7 in $40 \%$ yield.<smiles>O=C1c2ccccc2C(=O)c2cc(O)ccc21</smiles>

4<smiles>Oc1cc2cc3ccccc3cc2cc1C(O)(c1ccccc1)c1ccccc1</smiles>
7

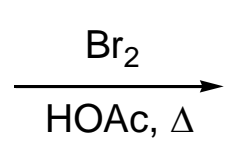

1) BuLi (4.4 eq.)<smiles>O=C1c2ccccc2C(=O)c2cc(Br)c(O)cc21</smiles>

5

$\mathrm{NaBH}_{4}, \mathrm{Na}_{2} \mathrm{CO}_{3}$ i-propanol<smiles>Oc1cc2cc3ccccc3cc2cc1Br</smiles>

6

Scheme 1.

Absorption spectra of $\mathbf{7}$ and $\mathbf{8}$ in $\mathrm{CH}_{3} \mathrm{CN}$ solution exhibit absorption band of lowest energy centered between $350-400 \mathrm{~nm}, 50 \mathrm{~nm}$ bathochromically shifted compared to that of anthracene. 
The $\mathrm{p} K_{\mathrm{a}}$ of 2-anthrol (8) in $\mathrm{CH}_{3} \mathrm{CN}-\mathrm{H}_{2} \mathrm{O}$ (1:9) in $\mathrm{S}_{0}$ and $\mathrm{S}_{1}$ was determined by $\mathrm{UV}$-vis and fluorescence titration, respectively $\left(\mathrm{p} K_{\mathrm{a}}=9.40 \pm 0.03 ; \mathrm{p} K_{\mathrm{a}} *=2.13 \pm 0.01\right.$, see the SI). Since it is known that intramolecular H-bonding with the benzyl alcohol increases acidity in 2-naphthol, ${ }^{16}$ the anticipated $\mathrm{p} K_{\mathrm{a}}$ values for $\mathbf{7}$ are expected to be somewhat lower.

The photophysical properties of 7 and $\mathbf{8}$ were investigated in $\mathrm{CH}_{3} \mathrm{CN}$ and $\mathrm{CH}_{3} \mathrm{CN}-\mathrm{H}_{2} \mathrm{O}(1: 1)$. Results are compiled in Table 1. Fluorescence in aqueous solution is quenched compared to that in neat $\mathrm{CH}_{3} \mathrm{CN}$. The quenching is due to proton transfer (PT) to solvent. Furthermore, $\Phi_{\mathrm{F}}$ for 7 in both solvents is lower than for $\mathbf{8}$. Since $\mathbf{8}$ cannot give QMs, the lower $\Phi_{\mathrm{F}}$ of $\mathbf{7}$ may be due to the photochemical pathway giving QM. Contrary to 2-methoxyanthracene, ${ }^{23} \mathbf{7}$ and $\mathbf{8}$ are characterized by a single exponential decay of fluorescence in $\mathrm{CH}_{3} \mathrm{CN}$. Addition of $\mathrm{H}_{2} \mathrm{O}$ changes the decay. For $\mathbf{8}$ it becomes double-exponential with a rise component (assigned to phenolate) that contributes more at longer wavelengths. For 7, the best fit was obtained by a threeexponential function with two rise components. Although a firm elucidation of the decay kinetics cannot be made at this time, the finding is consistent with a scheme that photodissociation of the anthrol $\mathrm{OH}$ of 7 in $\mathrm{S}_{1}$ triggers elimination of $\mathrm{OH}^{-}$(overall loss of $\mathrm{H}_{2} \mathrm{O}$ ) that leads to the formation of QM.

Table 1. Photophysical properties of 7 and 8 in $\mathrm{CH}_{3} \mathrm{CN}$ and $\mathrm{CH}_{3} \mathrm{CN}-\mathrm{H}_{2} \mathrm{O}$ (1:1).

\begin{tabular}{lll}
\hline & $\mathbf{7}$ & $\mathbf{8}$ \\
\hline$\Phi_{\mathrm{F}}\left(\mathrm{CH}_{3} \mathrm{CN}\right)^{\mathrm{a}}$ & $0.86 \pm 0.01$ & $0.88 \pm 0.05$ \\
$\Phi_{\mathrm{F}}\left(\mathrm{CH}_{3} \mathrm{CN}-\mathrm{H}_{2} \mathrm{O}\right)^{\mathrm{a}}$ & $0.39 \pm 0.01$ & $0.57 \pm 0.02$ \\
$\tau\left(\mathrm{CH}_{3} \mathrm{CN}\right) / \mathrm{ns}^{\mathrm{b}}$ & $17.8 \pm 0.1$ & $25.3 \pm 0.1$ \\
$\tau\left(\mathrm{CH}_{3} \mathrm{CN}-\mathrm{H}_{2} \mathrm{O}\right) / \mathrm{ns}^{\mathrm{b}}$ & $1.7 \pm 0.2$ phenolate & $15.4 \pm 0.1$ phenolate \\
\hline
\end{tabular}




$$
\begin{aligned}
& 8.1 \pm 0.2 \text { phenolate } \quad 25.3 \pm 0.1 \text { phenol } \\
& 24.5 \pm 0.1 \text { phenol }
\end{aligned}
$$

\footnotetext{
${ }^{\mathrm{a}}$ Quantum yields of fluorescence measured by use of quinine sulfate in $0.05 \mathrm{M}$ aqueous $\mathrm{H}_{2} \mathrm{SO}_{4}$ $\left(\Phi_{\mathrm{F}}=0.53\right)$ as a reference. ${ }^{24} \mathrm{~b}$ Fluorescence lifetimes measured by time-correlated single photon timing method.
}

Photochemical solvolysis of 7 was investigated by irradiations in $\mathrm{CH}_{3} \mathrm{OH}-\mathrm{H}_{2} \mathrm{O}$ (see the SI). Irradiations gave cleanly one product (9, Eq. 2). Conversion to 9 after $1 \mathrm{~h}$ of irradiation was higher in the presence of $20 \% \mathrm{H}_{2} \mathrm{O}(\approx 70 \%)$ than in neat $\mathrm{CH}_{3} \mathrm{OH}(\approx 50 \%)$. Such a finding has been reported in systems wherein the phenolic $\mathrm{OH}$ is not $\mathrm{H}$-bonded to the benzylic alcohol, ${ }^{19}$ and explained by a higher ability of phenols to deprotonate in $\mathrm{S}_{1}$ to clusters of $\mathrm{H}_{2} \mathrm{O}$ than $\mathrm{CH}_{3} \mathrm{OH}{ }^{25}$<smiles>COC(c1ccccc1)(c1ccccc1)c1cc2cc3ccccc3cc2cc1O</smiles>

Photosolvolysis of trityl derivatives, can in principle, take place via carbocations. To probe if $\mathbf{7}$ undergoes heterolytic cleavage of $\mathrm{OH}$ to give carbocation 13 (Scheme 2), irradiation of 70Me was performed. However, in the condition where 7 gave $72 \%$ of $\mathbf{9 , 7 0 M e ~ r e m a i n e d ~ u n c h a n g e d . ~}$ This finding indicates that the free phenolic $\mathrm{OH}$ is required for the formation of the solovolysis products. Furthermore, the finding is in accord with the photosolvolysis mechanism involving QM 12 (vide infra). 

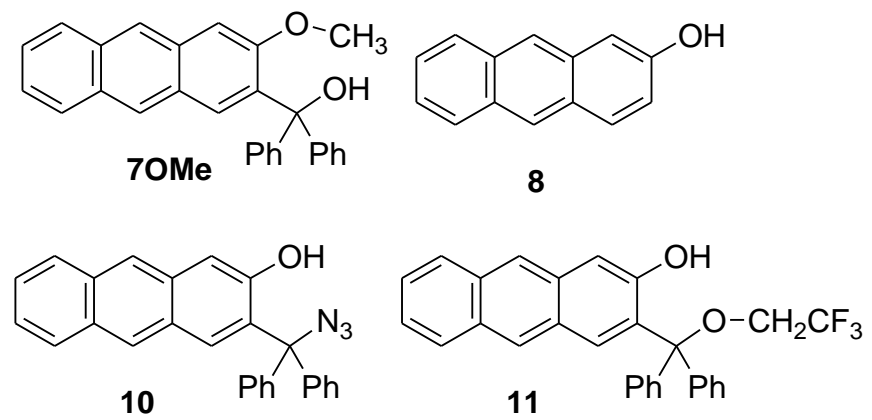

The scope of the photosolvolysis was further investigated by performing irradiations in the presence of other nucleophiles. Thus, azide adduct 10, and 2,2,2-trifluoroethanol (TFE) adduct 11 were isolated after irradiation of 7 in $\mathrm{CH}_{3} \mathrm{CN}-\mathrm{H}_{2} \mathrm{O}$, and $\mathrm{CH}_{3} \mathrm{CN}$-TFE, respectively, in $\approx 35-40 \%$ yield. The structures of the photoproducts $\mathbf{9}, \mathbf{1 0}$, and $\mathbf{1 1}$ were confirmed by NMR analysis. Additionally, all photosolvolyses were achieved by use of light > $350 \mathrm{~nm}(350 \mathrm{~nm}, 420 \mathrm{~nm}$, and vis-lamps, see the SI).

The efficiency of the photosolvolysis in $\mathrm{CH}_{3} \mathrm{OH}-\mathrm{H}_{2} \mathrm{O}$ (4:1) was determined by simultaneous use of three actinometers, valerophenone, $\mathrm{KI} / \mathrm{KIO}_{3}$ and ferioxalate. ${ }^{26}$ Irradiation was performed by use of monochromatic light at $254 \mathrm{~nm}$, and the composition of the irradiated solution of $\mathbf{7}$ was analyzed by HPLC. All actinometers gave $\Phi_{\mathrm{R}}=0.023 \pm 0.001$ for reaction.

To probe for QM and other plausible long-lived intermediates in the photochemistry of 7, LFP measurements were performed. The samples were excited by use of a Nd:YAG laser at $354 \mathrm{~nm}$. The measurements were performed in $\mathrm{CH}_{3} \mathrm{CN}$ and $\mathrm{CH}_{3} \mathrm{CN}-\mathrm{H}_{2} \mathrm{O}$ (1:1), and the difference was anticipated due to PT in the aqueous solution. In $\mathrm{CH}_{3} \mathrm{CN}$ solution $\left(\mathrm{N}_{2}\right.$ - and $\mathrm{O}_{2}$-purged), a band centered at $700 \mathrm{~nm}$ can be seen $(\tau=1.0 \pm 0.1 \mu \mathrm{s})$ that in the aqueous solution decays during the laser pulse. The transient is tentatively assigned to anthrol radical-cation which in the aqueous 
solution decays by deprotonation. ${ }^{27}$ In addition, in both solvents, more persistent transients were detected absorbing at shorter wavelengths $400-600 \mathrm{~nm}$. The decay is multi-exponential revealing several species. The major contribution to the band more centered at shorter wavelengths (400$500 \mathrm{~nm}$ ) decays slower $(\tau \approx 10-100 \mu \mathrm{s}$ and $\tau \approx 0.1-2 \mathrm{~s})$ and can also be seen in the transient spectra of $\mathbf{8}$ (see the supporting info). The transients are not affected by the presence of $\mathrm{O}_{2}$ and $\mathrm{H}_{2} \mathrm{O}$. The shorter-lived species is tentatively assigned to phenoxyl radical, according to the comparison with the published spectra and decay kinetics. ${ }^{28}$ In addition, a transient absorption was detected at 500-600 $\mathrm{nm}$ that decays multi-exponentially that could be quenched by nucleophiles (and not by $\mathrm{O}_{2}$ ). Therefore, this transient could tentatively be assigned to QMs or other electrophilic species (see the SI). However, due to complex decay kinetics and overlapping of the transient absorption spectra with several other species, no firm assignment to a QM can be made at this time.

A cleaner picture was obtained for LFP experiments carried out in TFE. TFE is a polar nonnucleophilic solvent in which electrophilic species such as QMs ${ }^{14,15,19}$ and carbocations ${ }^{29}$ exhibit longer lifetimes. LFP measurement for 7 in $\mathrm{O}_{2}$-purged TFE gave rise to a strong transient absorption centered at $580 \mathrm{~nm}$ that is formed within the laser pulse. It decayed $\left(k_{12 \rightarrow 13}=1.4 \times 10^{6}\right.$ $\left.\mathrm{s}^{-1}, \tau=690 \pm 10 \mathrm{~ns}\right)$ giving a new species absorbing at $520 \mathrm{~nm}$ (Fig.1) that also decays $\left(k_{13 \rightarrow 9}=\right.$ $\left.1.4 \times 10^{4} \mathrm{~s}^{-1}, \tau=84 \pm 3 \mu \mathrm{s}\right)$. Addition of ethanolamine, an ubiquitous quencher of $\mathrm{QMs},{ }^{14,19}$ changed the appearance of the spectra. However, the decay of the absorption at $580 \mathrm{~nm}$ was slower, and faster at $520 \mathrm{~nm}$, giving one band in the spectra. This finding suggests that two species are in equilibrium that is influenced by $\mathrm{pH}$ (ethanolamine is a base). Quenching with nucleophiles was successful for species absorbing at $520 \mathrm{~nm}$ (not affecting the faster decay at 580 $\mathrm{nm})$. The quenching rate constants are compiled in Table 2. According to the quenching data and 
the position of the maximum in the absorption spectra (comparison with the known spectra of trityl cation), ${ }^{30}$ the long-lived transient was assigned to carbocation 13. Since the short-lived transient is sensitive to acidity and in equilibrium with the cation, it is tentatively assigned to QM 12. Consequently, the first detected species in TFE by LFP is QM 12 which decays by protonation giving cation 13 (Scheme 2). Subsequent reaction with nucleophiles furnishes adducts. Interestingly, ethanolamine did not quench QM 12 in the tested concentration. The finding was explained by the ethanolamine basicity $\left(\mathrm{p} K_{\mathrm{a}}=9.5\right)$ which prevented fast protonation of QM 12 to cation 13.
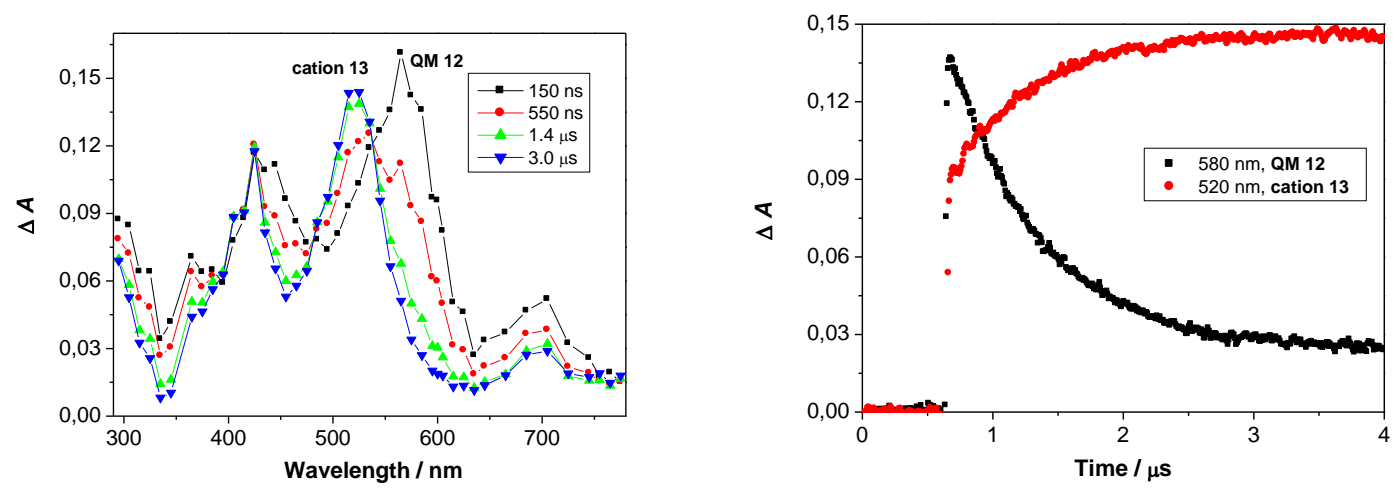

Figure 1. Transient absorption spectra of 7 in $\mathrm{O}_{2}$-purged 2,2,2-trifluoroethanol (TFE) (left), and growth and decay of the transient absorption at $520 \mathrm{~nm}$ (corresponding to cation 13) and $580 \mathrm{~nm}$ (corresponding to QM 12), respectively (right).

Table 2. Rate constants for the quenching of cation 13 with nucleophiles $\left(k_{\mathrm{q}}\right.$ or $\left.k_{13 \rightarrow 9} / \mathrm{s}^{-1} \mathrm{M}^{-1}\right){ }^{\mathrm{a}}$

\begin{tabular}{ll}
\hline Nucleophile & $k_{\mathrm{q}} / \mathrm{s}^{-1} \mathrm{M}^{-1}$ \\
\hline $\mathrm{CH}_{3} \mathrm{OH}$ & $9.8 \times 10^{3}$ \\
$\mathrm{H}_{2} \mathrm{O}$ & $1.6 \times 10^{3}$
\end{tabular}


$\mathrm{NaN}_{3}$

$2.1 \times 10^{8}$

${ }^{\mathrm{a}}$ Measurements performed in air-saturated TFE.

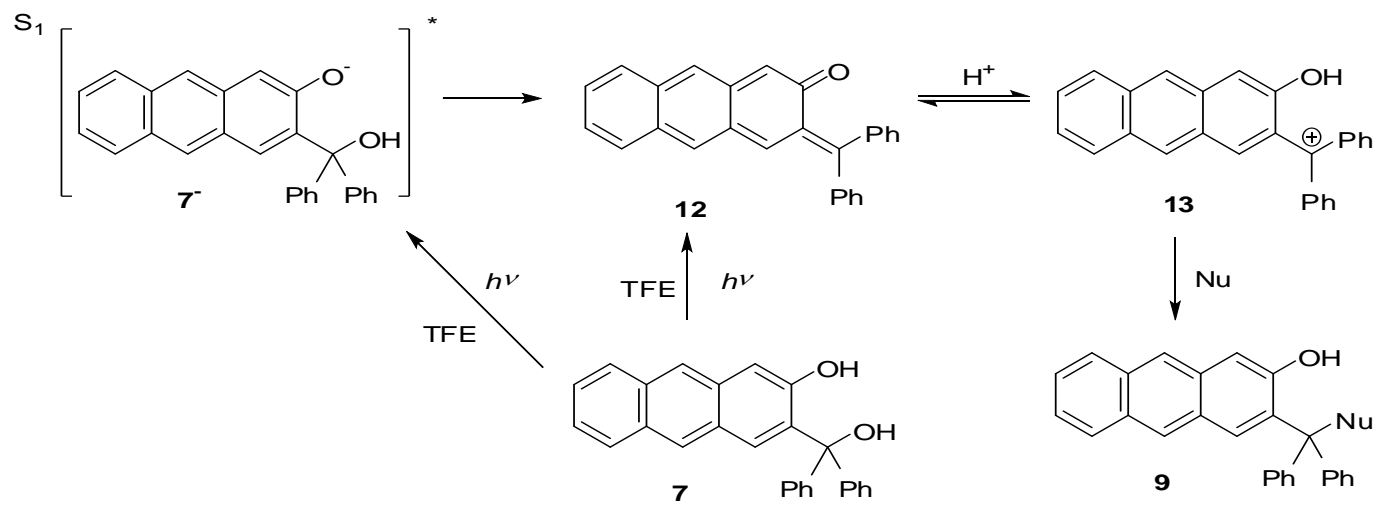

Scheme 2.

Cation 13 can also be formed in the $\mathrm{CH}_{3} \mathrm{CN}$ solution in a thermal acid-catalyzed reaction and detected by UV-vis spectroscopy. To the $\mathrm{CH}_{3} \mathrm{CN}$ solution was added $\mathrm{H}_{2} \mathrm{SO}_{4},(c=0.25 \mathrm{M})$ resulting in an immediate color change to red. The difference absorption spectrum has a maximum at $520 \mathrm{~nm}$ (see the Supporting info) with another band at longer wavelengths $(\approx 700$ $\mathrm{nm})$ and resembles the transient absorption of $\mathbf{7}$ measured in TFE and 1,1,1,3,3,3hexafluoroisopropanol (HFIP) after decay of the short-lived species assigned to QM 12. The transient in $\mathrm{CH}_{3} \mathrm{CN}$ decays $\left(\tau=0.63 \pm 0.02 \mathrm{~min}\right.$ ) probably giving $\mathrm{CH}_{3} \mathrm{CN}$ adduct 14 , resulting in a colorless solution. However, within 45-60 min, a new species is formed absorbing at 500-700 $\mathrm{nm}$, resulting in green color of the solution. The latter is tentatively assigned to QM 12 formed in a thermal acid-catalyzed reaction (Scheme 3). 


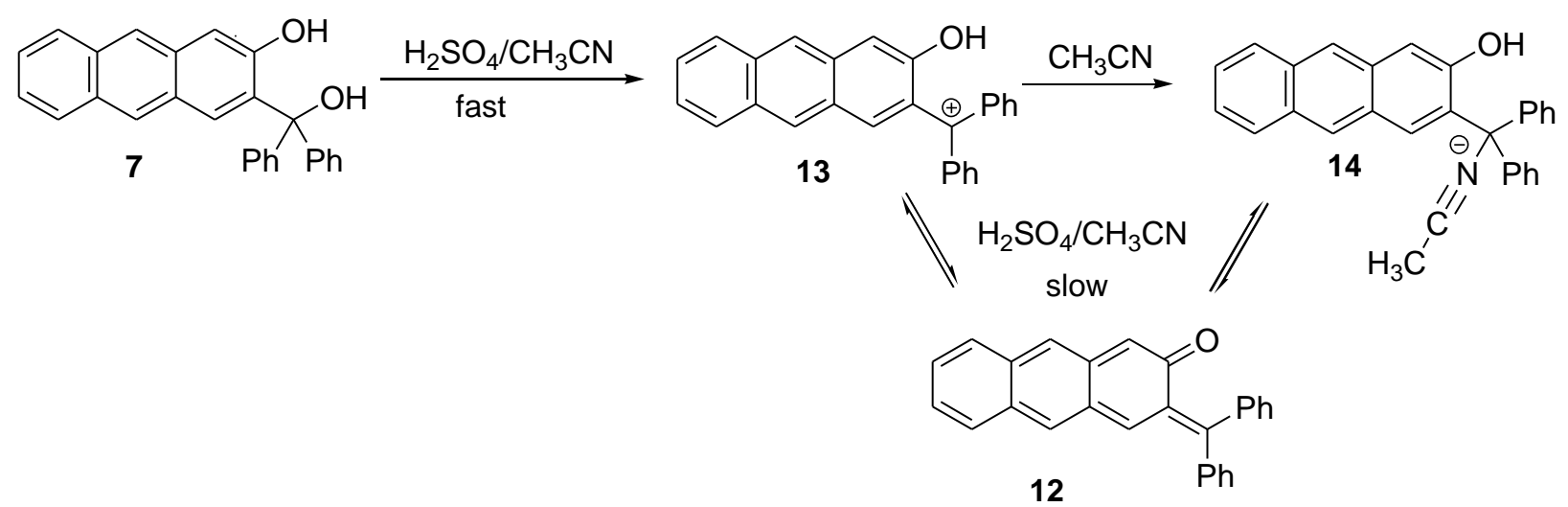

Scheme 3.

Antiproliferative investigation was conducted with 7 on three human cancer cell lines HCT 116 (colon), MCF-7 (breast), and H 460 (lung) with and without exposure to irradiation (350 nm and $420 \mathrm{~nm}$ ). In addition, the cells were irradiated in the absence of compounds to check for the cytotoxic effect of irradiations. The results are compiled in Table 3. Irradiation of the cells at 350 $\mathrm{nm}$ that were not treated with 7 induced up to maximum $25 \%$ of inhibition of tumor cell growth, whereas $420 \mathrm{~nm}$ did not cause any significant inhibition of tumor cell growth. On the other hand, exposure of the cells treated with 7 to irradiation induced higher cytotoxic effect than cells that were kept in dark. Consequently, higher photocytotoxicity of the compound allows for potential biological applications. However, for the actual photo-chemotherapeutic applications (except for maybe some forms of skin cancer) the compounds should bear chromophores absorbing at $>600$ $\mathrm{nm}$. Photochemicaly induced higher cytotoxicity of 7 suggests that the enhanced antiproliferative activity is due to the photo-generation of QMs. Although the exact mechanism of the enhanced antiproliferative activity was not determined, it is presumed that it is due to the reactivity of $\mathbf{1 2}$ or 13 with DNA, ${ }^{5,6}$ as well as some particular proteins (e.g. enzymes). ${ }^{2-4}$ Since the LFP experiments did not indicate formation of the triplet excited state, singlet oxygen probably did not induce 
antiproliferative activity. The investigation of biological action of different anthrol derivatives is currently under way and will be published separately.

Table 3. $\mathrm{IC}_{50}$ values (in $\left.\mu \mathrm{M}\right)$ for $7 .^{\mathrm{a}}$

\section{Cell lines}

Not irradiated

$3 \times 5 \min 350 \mathrm{~nm}$

$3 \times 5 \min 420 \mathrm{~nm}$

\section{HCT 116 MCF-7 H 460}

$\begin{array}{lll}21 \pm 0.3 & 20 \pm 0.5 & 19 \pm 1 \\ 2 \pm 0.4 & 4 \pm 3 & 3 \pm 1 \\ 2 \pm 0.4 & 2 \pm 0.1 & 2 \pm 0.2\end{array}$

${ }^{\mathrm{a}} \mathrm{IC}_{50}$; the concentration that causes $50 \%$ growth inhibition. Irradiation of the cells at $350 \mathrm{~nm}$ that were not treated with 7 induced up to maximum $25 \%$ inhibition of tumor cell growth, whereas irradiation of untreated cells at $420 \mathrm{~nm}$ showed no effect. For the calculation of $\mathrm{IC}_{50}$ see the experimental.

\section{Conclusion}

The presented results show that dehydration of 2-anthrol derivative 7 to QM 12 can be initiated in a photochemical reaction, and probably involves deprotonation of the phenol $\mathrm{OH}$ as the first step, followed by expulsion of the alcohol $\mathrm{OH}^{-}$. However, we could not time-resolve the formation of QM 12 (it is formed within the laser pulse). Therefore, we cannot rule out mechanisms that involve (i) excited state intramolecular proton transfer (ESIPT) from the phenol OH to the benzyl alcohol that is coupled with dehydration, or (ii) formation of a benzoxete intermediate that has a lifetime of $<50 \mathrm{~ns}$ and subsequently ring opens to form the QM.

Photogeneration of QMs in the anthrol series that can be initiated by near-visible light is of particular importance in biological systems. Preliminary results of antiproliferative investigations 
conducted for $\mathbf{7}$ on three human cancer cell lines showed higher activity for the cells that were irradiated. Consequently, we believe that anthrol derivatives have potential as a new class of photo-chemotherapeutic reagents, or as photo-labeling markers for biological systems.

\section{Experimental Section}

\section{Experimental procedure, general}

${ }^{1} \mathrm{H}$ and ${ }^{13} \mathrm{C}$ NMR spectra were recorded at 300 , or $600 \mathrm{MHz}$ at $\mathrm{rt}$ using TMS as a reference and chemical shifts were reported in ppm. Melting points were determined using a Mikroheiztisch apparatus and were not corrected. IR spectra were recorded on a spectrophotometer in $\mathrm{KBr}$ and the characteristic peak values were given in $\mathrm{cm}^{-1}$. HRMS were obtained on a MALDI TOF/TOF instrument. For the sample analysis a HPLC was used with $\mathrm{C} 18(1.8 \mu \mathrm{m}, 4.6 \times 50 \mathrm{~mm})$ column. HPLC runs were conducted at $\mathrm{rt}\left(\sim 25^{\circ} \mathrm{C}\right)$ and chromatograms were recorded using UV detector at $254 \mathrm{~nm}$. Other HPLC data were given in the supporting information, since the parameters vary. For the chromatographic separations silica gel $(0.05-0.2 \mathrm{~mm})$ was used. Irradiation experiments were performed in a reactor equipped with 16 lamps with the output at $350 \mathrm{~nm}$ or a reactor equipped with 8 lamps. During the irradiations, the irradiated solutions were continuously purged with $\mathrm{Ar}$ and cooled by a tap-water finger-condenser. Solvents for irradiations were of HPLC purity. Chemicals were purchased from the usual commercial sources and were used as received. 2-Hydroxyanthraquinone (4) was prepared from commercially available 2-aminoanthraquinone according to the known procedure. ${ }^{22}$ Solvents for chromatographic separations were used as they are delivered from supplier (p.a. grade) or purified by distillation $\left(\mathrm{CH}_{2} \mathrm{Cl}_{2}\right)$. Diethyl ether used for the reaction with BuLi was previously refluxed over $\mathrm{Na}$ and freshly distilled. 


\section{3-Bromo-2-hydroxyanthraquinone (5)}

The reaction was carried out in a two-neck round bottom flask $(250 \mathrm{~mL})$ equipped with a condenser and a dropping funnel. 2-Hydroxyanthraquinone (4, $4.54 \mathrm{~g}, 20.2 \mathrm{mmol})$ was dissolved in glacial acetic acid $(50 \mathrm{~mL})$ by heating using an oil bath. Bromine $(5 \mathrm{~mL}, 97.2 \mathrm{mmol})$ in glacial acetic acid $(50 \mathrm{~mL})$ was added to the refluxing reaction mixture over $4 \mathrm{~h}$, and the refluxing was continued overnight $(16 \mathrm{~h})$. The progress of the reaction was monitored by HPLC (see the SI). The next day the reaction mixture is allowed to cool to $\mathrm{rt}$ and poured on water ( $300 \mathrm{~mL})$. A saturated solution of $\mathrm{Na}_{2} \mathrm{SO}_{3}$ was added to destroy the excess of bromine. The yellow precipitate was filtered of, washed with water until neutral (tested with universal indicator paper) and dried in a desiccator over $\mathrm{KOH}$ overnight. The crude product contained 3-bromo-2hydroxyanthraquinone (5) and 1,3-dibromohydroxyanthraquinone in ratio 1:1. These two compounds were separated using column chromatography $\left(\mathrm{SiO}_{2}, \mathrm{CH}_{2} \mathrm{Cl}_{2} / \mathrm{EtOAc} / \mathrm{HOAc} 760: 40: 1\right.$ to 720:80:1) to obtain 1,3-dibromo-2-hydroxyanthraquinone 5 (2.93 g, $7.68 \mathrm{mmol}, 38 \%$ yield)

and 3-bromo-2-hydroxyanthraquinone $(2.45 \mathrm{~g}, 8.08 \mathrm{mmol}, 40 \%$ yield $)$ as yellow solid substances.

1,3-Dibromo-2-hydroxyanthraquinone, ${ }^{1} \mathrm{H}$ NMR $\left(300 \mathrm{MHz}, \mathrm{DMSO}-d_{6}\right) \delta / \mathrm{ppm} 8.34$ (s, 1H), 8.18-8.10 (m, 2H), 7.93-7.87 (m, 2H); IR (KBr) $v_{\max } / \mathrm{cm}^{-1} 3412(\mathrm{O}-\mathrm{H}), 3105(\mathrm{C}-\mathrm{H}), 3070(\mathrm{C}-\mathrm{H})$, $1672(\mathrm{C}=\mathrm{O})$.

3-Bromo-2-hydroxyanthraquinone (5), ${ }^{31}$ yellow solid, mp 235-245 ${ }^{\circ} \mathrm{C} ;{ }^{1} \mathrm{H}$ NMR $(300 \mathrm{MHz}$, DMSO- $\left.d_{6}\right) \delta / p p m ~ 11.97(\mathrm{~s}, 1 \mathrm{H}), 8.22(\mathrm{~s}, 1 \mathrm{H}), 8.17-8.11(\mathrm{~m}, 2 \mathrm{H}), 7.95-7.86(\mathrm{~m}, 2 \mathrm{H}), 7.64(\mathrm{~s}, 1 \mathrm{H})$; ${ }^{13} \mathrm{C}$ NMR (150 MHz, DMSO- $d_{6}$ ) $\delta / \mathrm{ppm} 182.0$ (s), 180.3 (s), 159.6 (s), 134.5 (d), 134.2 (d), 134.0 (s), $132.9(\mathrm{~s}), 132.8(\mathrm{~s}), 132.1(\mathrm{~d}), 126.6(\mathrm{~d}, 2 \mathrm{C}), 125.8(\mathrm{~s}), 116.6(\mathrm{~s}), 112.8(\mathrm{~d}) ; \mathrm{IR}(\mathrm{KBr}) v_{\max } / \mathrm{cm}^{-}$ 
${ }^{1} 3350(\mathrm{O}-\mathrm{H}), 1668(\mathrm{C}=\mathrm{O}), 1570(\mathrm{C}=\mathrm{O}), 1274(\mathrm{C}-\mathrm{H}), 719(\mathrm{C}-\mathrm{H})$; HRMS (MALDI) calculated for $\mathrm{C}_{14} \mathrm{H}_{7} \mathrm{BrKO}_{3}{ }^{+} 340.9210$, found 340.9204 .

\section{3-Bromo-2-hydroxyanthracene (6)}

$\mathrm{NaBH}_{4}(454 \mathrm{mg}, 12 \mathrm{mmol})$ was dissolved in $1 \mathrm{M} \mathrm{Na}_{2} \mathrm{CO}_{3}(\mathrm{aq})(30 \mathrm{~mL}), i$-propanol $(5 \mathrm{~mL})$ was added (foaming suppressor) and the mixture was heated until boiling point was achieved. 3Bromo-2-hydroxyanthraquinone $(\mathbf{5}, 910 \mathrm{mg}, 3 \mathrm{mmol})$ was added in three portions. The reaction mixture was refluxed for 15 min (longer reflux time usually produced more debromination product, 2-hydroxyanthracene). The reaction was quenched by careful addition of ice-cooled water $(30 \mathrm{~mL})$ followed by the addition of $3 \mathrm{M} \mathrm{HCl}$ until acidic reaction was achieved (tested by universal indicator paper). The product was collected by filtration, washed with water (until neutral reaction of the filtrate was achieved) and dried in evacuated desiccator (10 mbar) over $\mathrm{KOH}$ overnight. The crude product was purified on a column of silica gel using dichloromethane as eluent to give pure product $6(656 \mathrm{mg}, 2.4 \mathrm{mmol}, 80 \%$ yield over two steps) as yellow powder: mp 225-232 ${ }^{\circ} \mathrm{C} ;{ }^{1} \mathrm{H}$ NMR (300 MHz, $\mathrm{CDCl}_{3}$ ) $\delta / \mathrm{ppm} 8.27$ (s, 1H), 8.24 (s, 1H), 8.22 (s, 1H), 7.93 $(\mathrm{t}, J=7.2 \mathrm{~Hz}, 2 \mathrm{H}), 7.50(\mathrm{~s}, 1 \mathrm{H}), 7.48-7.38(\mathrm{~m}, 2 \mathrm{H}), 5.64(\mathrm{~s}, 1 \mathrm{H}) ;{ }^{13} \mathrm{C}$ NMR $(300 \mathrm{MHz}$, DMSO$\left.d_{6}\right) \delta / \mathrm{ppm} 150.9(\mathrm{~s}), 132.0(\mathrm{~d}), 131.7(\mathrm{~s}), 131.5(\mathrm{~s}), 129.7(\mathrm{~s}), 128.0(\mathrm{~d}), 127.7(\mathrm{~s}), 127.4(\mathrm{~d})$, 125.7 (d), 125.1 (d), 124.6 (d), 123.1 (d), 114.7 (s), 107.8 (d); IR (KBr) $v_{\max } / \mathrm{cm}^{-1} 3512(\mathrm{O}-\mathrm{H})$, 3049 (C-H); HRMS (MALDI) calculated for $\mathrm{C}_{14} \mathrm{H}_{9} \mathrm{BrO}^{+} 271.9831$, found 271.9829 .

\section{2-Hydroxy-3-(diphenylhydroxymethyl)anthracene (7)}

The reaction was carried out in a two-necked round bottom flask $(50 \mathrm{~mL})$ under a $\mathrm{N}_{2}$ inert atmosphere, equipped with a $\mathrm{N}_{2}$-balloon and a septum. The flask was charged with 3-bromo-2hydroxyanthracene $(6,286 \mathrm{mg}, 1.00 \mathrm{mmol})$ and $\operatorname{dry~} \mathrm{Et}_{2} \mathrm{O}(10 \mathrm{~mL})$ and cooled in an ice-methanol 
bath $\left(-15\right.$ to $\left.-10{ }^{\circ} \mathrm{C}\right)$. BuLi $(2.5 \mathrm{M}$ in hexanes, $1.2 \mathrm{~mL}, 3.00 \mathrm{mmol})$ was added dropwise over 15 min changing the color to brown. The reaction mixture was then emerged from the ice bath and stirred for $15 \mathrm{~min}$ at rt whereby all solid compound was dissolved giving a clear brown solution. The reaction mixture was then again cooled to $-10{ }^{\circ} \mathrm{C}$, and benzophenone $(900 \mathrm{mg}, 4.94 \mathrm{mmol}$ ) in dry $\mathrm{Et}_{2} \mathrm{O}(4 \mathrm{~mL})$ was added. Stirring was continued $1 \mathrm{~h}$ at $-10{ }^{\circ} \mathrm{C}$, then the reaction mixture was allowed to reach $\mathrm{rt}$ and the stirring was continued overnight. The reaction was quenched by careful addition of water $(15 \mathrm{~mL})$ and transferred to the separation funnel. A solution of $1 \mathrm{M}$ $\mathrm{NaOH}(20 \mathrm{~mL})$ and water $(100 \mathrm{~mL})$ was added and the aqueous layer was extracted with hexane $(2 \times 20 \mathrm{~mL})$ in order to remove unreacted benzophenone and the product of the reaction of benzophenone with BuLi. The aqueous layer was then acidified with $10 \%$ acetic acid and extracted with $\mathrm{Et}_{2} \mathrm{O}(3 \times 25 \mathrm{~mL})$. The ether extracts were combined and dried over anhydrous $\mathrm{MgSO}_{4}$. After filtration and removal of the solvent, the crude product was purified on a column of silica gel using dichloromethane as eluent to give pure 7 (763 mg, $2.03 \mathrm{mmol}, 40 \%$ yield) in the form of yellow-orange solid. mp 199-200 ${ }^{\circ} \mathrm{C} ;{ }^{1} \mathrm{H}$ NMR (300 MHz, DMSO- $d_{6}$ ) $\delta / \mathrm{ppm} 10.22$ (s, 1H), $8.28(\mathrm{~s}, 1 \mathrm{H}), 8.26(\mathrm{~s}, 1 \mathrm{H}), 7.95(\mathrm{t}, J=7.0 \mathrm{~Hz}, 2 \mathrm{H}), 7.44-7.24(\mathrm{~m}, 14 \mathrm{H}), 6.70(\mathrm{~s}, 1 \mathrm{H}) ;{ }^{13} \mathrm{C}$ NMR (300 MHz, DMSO- $\left.d_{6}\right) \delta /$ ppm 153.5, 145.9, 145.7, 136.5, 132.1, 131.8, 129.8, 128.6, 128.1, 128.0, 127.7, 127.6, 127.3, 127.1, 126.7, 126.6, 126.4, 126.2, 125.6, 124.2, 122.3, 108.5, 81.6, 74.2, 54.9; IR (KBr) $v_{\max } / \mathrm{cm}^{-1} 3367(\mathrm{O}-\mathrm{H}), 3051(\mathrm{C}-\mathrm{H}), 3024(\mathrm{C}-\mathrm{H}), 1447$ (C-H); HRMS (MALDI) calculated for $\mathrm{C}_{27} \mathrm{H}_{19} \mathrm{O}^{+} 359.1430$, found 359.1433 .

\section{2-Methoxy-3-(diphenylhydroxymethyl)anthracene (7OMe)}

The reaction was carried out in a two-neck round bottom flask $(25 \mathrm{~mL})$ under $\mathrm{N}_{2}$ atmosphere. 2Hydroxy-3-(diphenylhydroxymethyl)anthracene (7, $18 \mathrm{mg}, 48 \mu \mathrm{mol})$ was dissolved in acetone (8 $\mathrm{mL})$ and $\mathrm{K}_{2} \mathrm{CO}_{3}(50 \mathrm{mg}, 362 \mu \mathrm{mol})$ was added. The resulting suspension was heated at reflux 
resulting in a change of the color from pale yellow to yellow. MeI $(50 \mu \mathrm{L}, 803 \mu \mathrm{mol})$ was then added and the reaction mixture was stirred $5 \mathrm{~h}$ at $\mathrm{rt}$ (the color returns to pale yellow). The reaction mixture was then filtered and the filtrate evaporated on a rotary evaporator. The residue product was purified on short column of silica gel $(10 \times 1 \mathrm{~cm})$ using $\mathrm{CH}_{2} \mathrm{Cl}_{2}$ as eluent to give pure 2methoxy-3-(diphenylhydroxymethyl)anthracene (7OMe, $11 \mathrm{mg}, 31 \mu \mathrm{mol}, 64 \%$ yield) in the form of pale yellow solid. ${ }^{1} \mathrm{H}$ NMR $\left(600 \mathrm{MHz}, \mathrm{CDCl}_{3}\right) \delta / \mathrm{ppm} 8.25(\mathrm{~s}, 1 \mathrm{H}), 8.12(\mathrm{~s}, 1 \mathrm{H}), 7.92(\mathrm{~d}, J=$ $8.4 \mathrm{~Hz}, 1 \mathrm{H}), 7.86(\mathrm{~d}, J=8.4 \mathrm{~Hz}, 1 \mathrm{H}), 7.44-7.40(\mathrm{~m}, 2 \mathrm{H}), 7.34-7.28(\mathrm{~m}, 11 \mathrm{H}), 7.11(\mathrm{~s}, 1 \mathrm{H}), 5.19$ (s, 1H), 3.79 (s, 3H); $\left.{ }^{13} \mathrm{C} \mathrm{NMR} \mathrm{(150} \mathrm{MHz,} \mathrm{CDCl}_{3}\right) \delta / \mathrm{ppm} 155.9$ (s), 146.3 (s), 136.8 (s), 132.3 (s), 131.8 (s), 130.7 (s), 130.1 (d), 128.1 (d), 128.0 (d), 127.8 (d), 127.7 (d), 127.5 (d), 127.3 (s), 127.0 (d), 125.6 (d), 124.6 (d), 123.5 (d), 105.7 (d), 82.1 (s), 55.6 (q); IR (KBr) $v_{\max } / \mathrm{cm}^{-1} 3448$ (O-H), 2920 (C-H), 2851 (C-H), 1458 (C-H); HRMS (MALDI) calculated for $\mathrm{C}_{28} \mathrm{H}_{22} \mathrm{O}_{2}{ }^{+}$ 390.1614 , found 390.1624 .

\section{Irradiation experiments}

\section{Preparative photomethanolysis}

In a quartz vessel was placed a $\mathrm{CH}_{3} \mathrm{OH}-\mathrm{H}_{2} \mathrm{O}(4: 1)$ solution of compound $7\left(100 \mathrm{~mL}, \mathrm{c} \sim 4 \times 10^{-5}\right.$ M) and irradiated in a Rayonet reactor using 16 lamps at $350 \mathrm{~nm}$ for 30-120 min. Prior to, and during the irradiation, the solution was continuously purged with a stream of Ar and cooled by a coldfinger condenser. After 90 min of irradiation, the solvent was removed on a rotary evaporator and the residue was dried (water was removed as azeotrope with toluene). The photoproduct was purified on a column of silica gel $(4 \times 1 \mathrm{~cm})$ using $\mathrm{CH}_{2} \mathrm{Cl}_{2}$ as eluent to obtain pure 9 (13 $\mathrm{mg}, 33$ $\mu \mathrm{mol}, 84 \%$ yield) in the form of pale yellow film on the walls of the flask. ${ }^{1} \mathrm{H}$ NMR $(600 \mathrm{MHz}$, $\left.\mathrm{CDCl}_{3}\right) \delta / \mathrm{ppm} 8.68(\mathrm{~s}, 1 \mathrm{H}), 8.20(\mathrm{~s}, 1 \mathrm{H}), 8.19(\mathrm{~s}, 1 \mathrm{H}), 7.90(\mathrm{~d}, J=8.4 \mathrm{~Hz}, 1 \mathrm{H}),, 7.86(\mathrm{~d}, J=8.4$ 
$\mathrm{Hz}, 1 \mathrm{H}), 7.68(\mathrm{~s}, 1 \mathrm{H}), 7.46-7.42(\mathrm{~m}, 4 \mathrm{H}), 7.41-7.31(\mathrm{~m}, 8 \mathrm{H}), 3.35(\mathrm{~s}, 3 \mathrm{H}) ;{ }^{13} \mathrm{C}$ NMR $(150 \mathrm{MHz}$, $\left.\mathrm{CDCl}_{3}\right) \delta / \mathrm{ppm} 153.9$ (s), 140.6 (s), 132.6 (s), 132.4 (s), 132.1 (s), 130.5 (d), 129.0 (d), 128.1 (d), 128.0 (d), 127.9 (d), 127.5 (d), 126.9 (s), 126.7 (d), 125.5 (d), 124.2 (d), 123.0 (d), 110.1 (d), 53.1 (q); IR (KBr) $v_{\max } / \mathrm{cm}^{-1} 3421(\mathrm{O}-\mathrm{H}), 3055(\mathrm{C}-\mathrm{H}), 2970(\mathrm{C}-\mathrm{H}), 2924(\mathrm{C}-\mathrm{H}), 2953(\mathrm{C}-\mathrm{H}), 1448$ (CH); HRMS (MALDI) calculated for $\mathrm{C}_{27} \mathrm{H}_{20} \mathrm{O}^{+} 360.1509$, found 360.1506 .

\section{Irradiation in the presence of $\mathrm{NaN}_{3}$}

In a quartz vessel was placed $\mathrm{CH}_{3} \mathrm{CN}$ solution $(70 \mathrm{~mL})$ of compound 7 (15 mg, $\left.40 \mu \mathrm{mol}\right)$, and solution of $\mathrm{NaN}_{3}(1 \mathrm{~g}, 15 \mathrm{mmol})$ in water $(30 \mathrm{~mL})$ was added. Upon addition of $\mathrm{NaN}_{3}$ solution changed color to yellow, probably due to deprotonation of the anthrol $\mathrm{OH}$ (caused by hydrolysis of the azide). The solution was irradiated in a reactor using 12 lamps at $350 \mathrm{~nm}$ for $2 \mathrm{~h}$. Prior to, and during the irradiation, the solution was continuously purged with a stream of Ar and cooled using a coldfinger condenser. After the irradiation, the reaction mixture was poured on water $(150 \mathrm{~mL})$ and extracted with diethyl ether $(3 \times 20 \mathrm{~mL})$. The organic extracts were combined and washed with water $(2 \times 100 \mathrm{~mL})$. The organic phase was separated and dried over anhydrous $\mathrm{MgSO}_{4}$, filtered and the solvent was removed on a rotary evaporator. The crude product was chromatographed on a short column of silica gel $(10 \times 1 \mathrm{~cm})$ using $\mathrm{CH}_{2} \mathrm{Cl}_{2}$ as an eluent to obtain pure product $10(6 \mathrm{mg}, 15 \mathrm{mmol}, 38 \%$ yield $)$ in the form of thin yellowish film on the walls of

the flask. ${ }^{1} \mathrm{H}$ NMR $\left(600 \mathrm{MHz}, \mathrm{CDCl}_{3}\right) \delta / \mathrm{ppm} 8.23(\mathrm{~s}, 1 \mathrm{H}), 8.18(\mathrm{~s}, 1 \mathrm{H}), 7.92(\mathrm{~d}, J=8.4 \mathrm{~Hz}, 1 \mathrm{H})$, $7.86(\mathrm{~d}, J=8.4 \mathrm{~Hz}, 1 \mathrm{H}), 7.44-7.41(\mathrm{~m}, 8 \mathrm{H}), 7.39(\mathrm{~s}, 1 \mathrm{H}), 7.30(\mathrm{~m}, 4 \mathrm{H}), 6.92(\mathrm{~s}, 1 \mathrm{H}) ;{ }^{13} \mathrm{C} \mathrm{NMR}$ $\left(150 \mathrm{MHz}, \mathrm{CDCl}_{3}\right) \delta / \mathrm{ppm} 152.4$ (s), 140.9 (s), 132.54 (s), 132.46 (s), 131.4 (s), 130.9 (d), 130.4 (s), 128.6 (d), 128.4 (d), 128.3 (d), 128.2 (d), 128.1 (d), 127.6 (d), 127.1 (d), 126.8 (s), 125.6 (d), 124.5 (d) 123.2 (d), 111.3 (d), 29.6 (s); IR (KBr) $v_{\max } / \mathrm{cm}^{-1} 3421$ (O-H), 3057 (C-H), 2924 (C-H), $2853(\mathrm{C}-\mathrm{H}), 2104(\mathrm{~N} \equiv \mathrm{N})$; HRMS (MALDI) calculated for $\mathrm{C}_{27} \mathrm{H}_{20} \mathrm{O}^{+} 360.1509$, found 360.1523. 


\section{Irradiation in the presence of 2,2,2-trifluoroethanol (TFE)}

In a quartz vessel was placed a $\mathrm{CH}_{3} \mathrm{CN}$ solution $(90 \mathrm{~mL})$ of compound $7(13 \mathrm{mg}, 35 \mu \mathrm{mol})$ and 2,2,2-trifluoroethanol $(10 \mathrm{~mL})$ was added. The solution was irradiated in a reactor using 12 lamps at $350 \mathrm{~nm}$ for $30 \mathrm{~min}$. Prior to, and during the irradiation, the solution was continuously purged with a stream of Ar and cooled using a cold finger condenser. After the irradiation, the solvent was evaporated on rotary evaporator. The crude product was chromatographed on a short column of silica gel $(10 \times 1 \mathrm{~cm})$ using $\mathrm{CH}_{2} \mathrm{Cl}_{2}$ as an eluent to obtain the pure product $11(6 \mathrm{mg}, 13 \mu \mathrm{mol}$, $37 \%$ yield) in the form of thin yellowish film on the walls of the flask. ${ }^{1} \mathrm{H}$ NMR (600 MHz, $\left.\mathrm{CDCl}_{3}\right) \delta / \mathrm{ppm} 8.22(2 \mathrm{~s}, 2 \mathrm{H}), 7.92(\mathrm{~d}, J=8.8 \mathrm{~Hz}, 1 \mathrm{H}), 7.87(\mathrm{~d}, J=8.8 \mathrm{~Hz}, 1 \mathrm{H}), 7.72(\mathrm{~s}, 1 \mathrm{H})$, 7.49-7.45 (m, 4H), 7.43-7.35 (m, 9H), $3.77\left(\mathrm{q},{ }^{3} J_{\mathrm{H}, \mathrm{F}}=8.1 \mathrm{~Hz}, 2 \mathrm{H}\right),{ }^{13} \mathrm{C} \mathrm{NMR}\left(150 \mathrm{MHz}, \mathrm{CDCl}_{3}\right)$

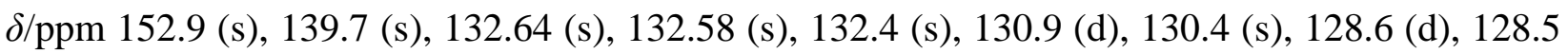
(d), 128.3 (d), 128.1 (d), 127.6 (d), 127.0 (d), 126.9 (s), 125.8 (d), 125.5 (q, $\left.{ }^{1} J_{\mathrm{C}, \mathrm{F}}=251 \mathrm{~Hz}\right)$, 124.5 (d), 123.2 (d), 111.0 (d), 62.7 (q, $\left.{ }^{3} J_{\mathrm{C}, \mathrm{H}}=34 \mathrm{~Hz}\right), 29.6(\mathrm{~s})$; IR (KBr) $v_{\max } / \mathrm{cm}^{-1} 3435(\mathrm{O}-\mathrm{H})$, 3059 (C-H), 2924 (C-H), 2953 (C-H), 1281 (C-F), 1165 (C-F); HRMS (MALDI) calculated for $\mathrm{C}_{27} \mathrm{H}_{20} \mathrm{O}^{+} 360.1509$, found 360.1504 .

\section{Quantum yield of the photomethanolysis reaction}

Quantum yield of the photomethanolysis reaction was determined by use of three actinometers simultaneously: valerophenone, ${ }^{24}$ ferrioxalate ${ }^{25}$ and $\mathrm{KI} / \mathrm{KIO}_{3}{ }^{32}$ A solution of ferrioxalate actinometer was handled in dark. The measurement was performed in five quartz cells with the same dimensions (square, for UV-vis measurement, ca. $3 \mathrm{~mL}$ ), that were during the irradiations wrapped in black paper, except from the front side to ensure the controlled absorption of the light 
from one side only (no absorption of the radiation reflected from the walls of the reactor). The solution of compound 7 in $\mathrm{CH}_{3} \mathrm{OH}-\mathrm{H}_{2} \mathrm{O}$ (4:1), as well as the solution of valerophenone in $\mathrm{CH}_{3} \mathrm{CN}-\mathrm{H}_{2} \mathrm{O}$ (4:1) were freshly prepared and their concentrations adjusted to have absorbances 0.4-0.8 at $254 \mathrm{~nm}$. After adjustment of the concentrations and measurement of the corresponding $\mathrm{UV}$-vis spectra, $2.5 \mathrm{~mL}$ of the solution was transferred to the quartz cell and the solutions were purged with a stream of $\mathrm{N}_{2}$ (20 min each), and then, sealed with a cap. Freshly prepared solution of potassium trioxalatoferrate(III) $\left(0.012 \mathrm{M} \mathrm{K}_{3}\left[\mathrm{Fe}\left(\mathrm{C}_{2} \mathrm{O}_{4}\right)_{3}\right] \times 3 \mathrm{H}_{2} \mathrm{O}\right.$ in $\left.0.05 \mathrm{M} \mathrm{H}_{2} \mathrm{SO}_{4}\right)(2.5 \mathrm{~mL})$ and the solution containing potassium iodate $(0.1 \mathrm{M})$ and potassium iodide $(0.6 \mathrm{M})$ in borate buffer $(\mathrm{pH}=9.25)(2.5 \mathrm{~mL})$ were placed in the third and the forth quartz cell, respectively. Potassium trioxalatoferrate(III) $(2.5 \mathrm{~mL})$ was placed in the fifth cell which was not irradiated (blank sample). Before the irradiation, $A_{352}$ for the solution of $\mathrm{KI} / \mathrm{KIO}_{3}$ was measured. The cells were placed in a holder which ensured equal distance of all samples from the lamp and irradiated at the same time in the reactor with 1 lamp at $254 \mathrm{~nm}$ for $30 \mathrm{~s}$. Before and after the irradiation, the samples were taken from the cells by use of a syringe and analyzed by HPLC to determine conversion of 7 to 9 and valerophenone to acetophenone. The conversion did not exceed $30 \%$ to avoid change of the absorbance, or filtering of the light by the product. $A_{352}$ of $\mathrm{KI} / \mathrm{KIO}_{3}$ actionometer solution was measured to determine the concentration of $\mathrm{I}_{3}{ }^{-}$using $\varepsilon 352=27600 \mathrm{M}^{-}$ ${ }^{1} \mathrm{~cm}^{-1} \cdot 32$ To both solutions of ferrioxalate actinometer (irradiated and blank) a solution of phenantroline was added $(0.5 \mathrm{~mL}, 0.1 \%$ phenanthroline in buffer containing $1.65 \mathrm{M} \mathrm{NaOAc}$ and $\left.0.5 \mathrm{M} \mathrm{H}_{2} \mathrm{SO}_{4}\right)$ and $A_{510}$ was measured. The concentration of $\mathrm{Fe}^{\mathrm{II}}$ was determined using $\varepsilon_{510}=$ $11100 \mathrm{M}^{-1} \mathrm{~cm}^{-1} \cdot{ }^{25}$ From the conversion (valerophenone) and concentration of the photoproducts (in ferrioxalate and $\mathrm{KI} / \mathrm{KIO}_{3}$ ) irradiance was calculated. The similar values were obtained for all three actinometers. These values and the value of conversion $\mathbf{7} \rightarrow \mathbf{9}$ were used to calculate the 
quantum yield of photomethanolysis for compound 7. The mean value of three measurements was reported. All equations for the calculation of quantum yields are given in the supporting info.

\section{Steady State and Time-Resolved Fluorescence Measurements}

The steady state measurements were performed a luminescence spectrometer. The samples were dissolved in $\mathrm{CH}_{3} \mathrm{CN}$, or $\mathrm{CH}_{3} \mathrm{CN}-\mathrm{H}_{2} \mathrm{O}$ (1:1) and the concentrations were adjusted to have absorbances at the excitation wavelength $(330,350$, or $370 \mathrm{~nm})<0.1$. Solutions were purged with nitrogen for $30 \mathrm{~min}$ prior to analysis. The measurements were performed at $20{ }^{\circ} \mathrm{C}$. Fluorescence quantum yields were determined by comparison of the integral of the emission bands with the one of quinine sulfate in $0.05 \mathrm{M}$ aqueous $\mathrm{H}_{2} \mathrm{SO}_{4}\left(\Phi_{\mathrm{F}}=0.53\right)$. The measurements were performed in triplicate and the mean value reported. Typically, three absorption traces were recorded (and averaged) and three fluorescence emission traces, exciting at three different wavelengths. Three quantum yields were calculated and the mean value reported.

Fluorescence decays were obtained on an instrument equipped with a light emitting diode (excitation wavelength $375 \mathrm{~nm}$ ), using time-correlated single photon counting technique in 1023 channels. Histograms of the instrument response functions (using LUDOX scatterer), and sample decays were recorded at 410,420,450 and $550 \mathrm{~nm}$ until they reached $2 \times 10^{3}$ counts in the peak channel. The half width of the instrument response function was $\approx 0.2 \mathrm{~ns}$. The time increment per channel was 0.02441 ns. Obtained histograms were fitted as sums of exponential using Gaussianweighted non-linear least-squares fitting based on Marquardt-Levenberg minimization implemented in the software package of the instrument. The fitting parameters (decay times and pre-exponential factors) were determined by minimizing the global reduced chi-square $\chi^{2}$. 
Additional graphical method was used to judge the quality of the fit that included plots of surfaces ("carpets") of the weighted residuals vs. channel number.

\section{Determination of $\mathrm{p} K_{\mathrm{a}}$ and $\mathrm{p} K_{\mathrm{a}} *$ for 2-anthrol (8)}

\section{UV-vis titration}

A stock solution of the compound $\mathbf{8}$ was prepared by dissolving $0.50 \mathrm{mg}$ of $\mathbf{8}$ in $500 \mu \mathrm{L} \mathrm{CH}_{3} \mathrm{CN}$. $195 \mu \mathrm{L}$ of the stock solution was diluted to $200 \mathrm{~mL}$ with $\mathrm{CH}_{3} \mathrm{CN}-\mathrm{H}_{2} \mathrm{O}$ (1:9) to adjust the concentration of the compound to $5.0 \times 10^{-6} \mathrm{M}$ (for titration I). For titration II, $7.93 \mathrm{mg}$ of $\mathbf{8}$ was dissolved in $200 \mathrm{~mL} \mathrm{CH} \mathrm{CN}_{3} / \mathrm{H}_{2} \mathrm{O}(2: 8) .150 .0 \mathrm{~mL}$ of each solution was titrated with a diluted solution of $\mathrm{NaOH}$ (until $\mathrm{pH} 12.7$ was reached). The $\mathrm{pH}$ was measured by a $\mathrm{pH}$-meter and UV-vis spectra were recorded on an instrument. The measurement was performed at $25^{\circ} \mathrm{C}$. The resulting UV-vis spectra were processed by multivariate nonlinear regression analysis using Specfit program.

\section{Fluorescence titration}

A stock solution of the compound $\mathbf{8}$ was prepared by dissolving $1 \mathrm{mg}$ of $\mathbf{8}$ in $1000 \mu \mathrm{L} \mathrm{CH}_{3} \mathrm{CN}$. $855 \mu \mathrm{L}$ of the stock solution was diluted to $200 \mathrm{~mL}$ with $\mathrm{CH}_{3} \mathrm{CN}-\mathrm{H}_{2} \mathrm{O}$ (1:9) to adjust the concentration of the compound to $2.2 \times 10^{-5} \mathrm{M}$. $150.0 \mathrm{~mL}$ of the solution was basified with a diluted solution of $\mathrm{NaOH}$ (until $\mathrm{pH} 12.3$ was reached) and titrated with a diluted solution of $\mathrm{H}_{2} \mathrm{SO}_{4}$ (until $\mathrm{pH} 0.5$ was reached). The $\mathrm{pH}$ was measured by a $\mathrm{pH}$-meter and fluorescence spectra were recorded on an instrument (slits $2 \times 2.5 \mathrm{~nm}$ ). The measurement was performed at $25^{\circ} \mathrm{C}$. The resulting fluorescence spectra were processed by multivariate nonlinear regression analysis using Specfit program. 


\section{Laser Flash Photolysis (LFP)}

All LFP studies were conducted at the University of Victoria LFP facility employing a YAG laser, with a pulse width of $10 \mathrm{~ns}$ and excitation wavelength $355 \mathrm{~nm}$. Static cells $(0.7 \mathrm{~cm})$ were used and solutions were purged with nitrogen or oxygen for 20 min prior to measurements. Absorbances at $355 \mathrm{~nm}$ were $\sim 0.4$.

\section{Antiproliferative investigation}

The experiments were carried out on three human carcinoma cell lines HCT 116, MCF-7 and H 460. Cells were cultured as monolayers and maintained in Dulbecco's modified Eagle medium (DMEM) supplemented with $10 \%$ fetal bovine serum (FBS), 2mM L-glutamine, $100 \mathrm{U} / \mathrm{mL}$ penicillin, and $100 \mu \mathrm{g} / \mathrm{mL}$ streptomycin in a humidified atmosphere with $5 \% \mathrm{CO}_{2}$ at $37^{\circ} \mathrm{C}$.

The cells were inoculated in parallel on two 96 -well microtiter plates on day 0 , at $1.5 \times 10^{4}$ cells/mL. Test agents were added in ten-fold dilutions $\left(10^{-8}\right.$ to $\left.10^{-4} \mathrm{M}\right)$ on the next day and incubated for further $72 \mathrm{~h}$. Working dilutions were freshly prepared on the day of testing. One of the plates was left in the dark, while the other was irradiated in a reactor (6 lamps $350 \mathrm{~nm}$ or 420 $\mathrm{nm}, 5 \mathrm{~min})$ 4, 24, and 48 hours after the addition of the compounds. After $72 \mathrm{~h}$ of incubation the cell growth rate was evaluated by performing the MTT assay ${ }^{33}$ (for the irradiated and nonirradiated cells) which detects dehydrogenase activity in viable cells. The absorbance $(A)$ was measured on a microplate reader at $570 \mathrm{~nm}$. The absorbance is directly proportional to the number of living, metabolically active cells. The percentage of growth (PG) of the cell lines was calculated according to one or the other of the following two expressions:

If $\left(\right.$ mean $A_{\text {test }}-$ mean $\left.A_{\text {tzero }}\right) \geq 0$, then PG $=100 \times\left(\right.$ mean $A_{\text {test }}-$ mean $\left.A_{\text {tzero }}\right) /\left(\right.$ mean $A_{\text {ctrl }}-$ mean

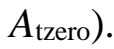


If $\left(\right.$ mean $A_{\text {test }}-$ mean $\left.A_{\text {tzero }}\right)<0$, then: PG $=100 \times\left(\right.$ mean $A_{\text {test }}-$ mean $\left.A_{\text {tzero }}\right) / A_{\text {tzero, }}$, where the mean $A_{\text {tzero }}$ is the average of absorbance measurements before exposure of cells to the test compound, the mean $A_{\text {test }}$ is the average of absorbance measurements after the desired period of time and the mean $A_{\text {ctrl }}$ is the average of absorbance measurements after the desired period of time with no exposure of cells to the test compound. In the experiments where the cells were irradiated, $A_{\text {ctrl }}$ represents irradiated control cells. After irradiation at $350 \mathrm{~nm} 25 \%$ growth inhibition compared to $A_{\text {ctrl }}$ without irradiation was observed, while after the irradiation at $420 \mathrm{~nm}$ no significant growth inhibition was observed.

The results are expressed as $\mathrm{IC}_{50}$, which is the concentration necessary for $50 \%$ of inhibition. The $\mathrm{IC}_{50}$ values are calculated from concentration-response curves using linear regression analysis by fitting the test concentrations that give PG values above and below the reference value (i.e. 50\%). Each test was performed in quadruplicate in at least two individual experiments.

\section{Acknowledgements}

This work was supported by the Croatia Foundation for Science (HRZZ grant no. 02.05/25), the Ministry of Science Education and Sports of the Republic of Croatia (grant No. 098-09829332911), the Natural Sciences and Engineering Research Council (NSERC) of Canada, and the University of Victoria.

Supporting information The contents of Supporting Information includes copies of the ${ }^{1} \mathrm{H}$ and ${ }^{13} \mathrm{C}$ NMR spectra, UV-vis, fluorescence, and LFP data. This material is available free of charge via the Internet at http://pubs.acs.org. 


\section{References:}

1. Rokita, S. E. (Ed.), Quinone Methides, Wiley, Hoboken, 2009.

2. (a) McCracken, P. G.; Bolton, J. L.; Thatcher, G. R. J. J. Org. Chem. 1997, 62, 1820-1825; (b) Modica, E.; Zanaletti, R.; Freccero, M.; Mella, M. J. Org. Chem. 2001, 66, 41-52.

3. Bolton, J. L.; Turnipseed, S. B.; Thompson, J. A. Chem. Biol. Interact. 1997, 107, 185-200.

4. (a) McDonald, I. A.; Nyce, P. L.; Jung, M. J.; Sabol, J. S. Tetrahedron Lett. 1991, 32, 887-890;

(b) Wang, Q.; Myers, J. K.; Cohen, J. D.; Widlanski, T. S. J. Am. Chem. Soc., 1995, 117, 1104911054; (c) Storwell, J. K.; Widlanski, T. S.; Kutaleladze, T. G.; Raines, R. T. J. Org. Chem. 1995, 60, 6930-6936; (d) Cabaret, D.; Adediran, S. A.; Gonzalez, M. J. G.; Pratt, R. F.; Wakselman, M. J. Org. Chem. 1999, 64, 713-720.

5. (a) Rokita, S. E.; Yang, J.; Pande, P.; Greenberg, W. A. J. Org. Chem. 1997, 62, 3010-3012;

(b) Veldhuyzen, W. F.; Shallop, A. J.; Jones, R. A.; Rokita, S. E. J. Am. Chem. Soc. 2001, 123, 11126-11132.

6. (a) Pande, P.; Shearer, J.; Yang, J.; Greenberg, W. A.; Rokita, S. E. J. Am. Chem. Soc. 1999, 121, 6773-6779; (b) Wang, P.; Liu, R.; Wu, X.; Ma, H.; Cao, X.; Zhou, P.; Zhang, J.; Weng, X.; Zhang, X. L.; Zhou, X.; Weng, L. J. Am. Chem. Soc. 2003, 125, 1116-1117; (c) Richter, S. N.; Maggi, S.; Colloredo Mels, S.; Palumbo, M.; Freccero, M. J. Am. Chem. Soc. 2004, 126, 1397313979; (d) Verga, D.; Richter, S. N.; Palumbo, M.; Gandolfi, R.; Freccero, M. Org. Biomol. Chem. 2007, 5, 233-235.

7. (a) Wolkenberg, S. E.; Boger, D. L. Chem. Rev., 2002, 102, 2477-2495; (b) Wang, P.; Song, Y.; Zhang, L.; He, H.; Zhou, X. Curr. Med. Chem. 2005, 12, 2893-2913. 
8. (a) Li, V. S.; Kohn, H. J. Am. Chem. Soc., 1991, 113, 275-283; (b) Han, I.; Russell, D. J.; Kohn, H. J. Org. Chem. 1992, 57, 1799-1807; (c) Tomasz, M.; Das, A.; Tang, K. S.; Ford, M. G. J.; Minnock, A.; Musser, S. M.; Waring, M. J. J. Am. Chem. Soc., 1998, 120, 11581-11593.

9. (a) Abdella, B. R. J.; Fisher, J. Environ. Health Perspect. 1985, 64, 4-18; (b) Engholm, M.; Koch, T. H. J. Am. Chem. Soc. 1989, 111, 8291-8293; (c) Angle S. R.; Yang, W. J. Am. Chem. Soc. 1990, 112, 4524-4528; (d) Gaudiano, G.; Frigerio, M.; Bravo, P.; Koch, T. H. J. Am. Chem. Soc. 1990, 112, 6704-6709; (e) Gaudiano, G.; Koch, T. H. Chem. Res. Toxicol. 1991, 4, 2-16; (f) Angle S. R.; Yang, W. J. Org. Chem. 1992, 57, 1092-1097; (f) Angle, S. R.; Rainer, J. D.; Woytowicz, C. J. Org. Chem. 1997, 62, 5884-5892.

10. Koch, T. H.; Barthel, B. L.; Kalet, B. T.; Rudnicki, D. L.; Post, G. C.; Burkhart, D. J. Top. Curr. Chem. 2008, 283, 141-170.

11. Diao, L.; Yang, C.; Wan, P. J. Am. Chem. Soc. 1995, 117, 5369-5370.

12. Chiang, Y.; Kresge, A. J.; Zhu, Y. J. Am. Chem. Soc. 2002, 124, 6349-6356.

13. Nakatani, K.; Higashida, N.; Saito, I. Tetrahedron Lett. 1997, 38, 5005-5008.

14. (a) Brousmiche, D.; Xu, M.; Lukeman, M.; Wan, P. J. Am. Chem. Soc. 2003, 125, 1296112970; (b) Xu, M.; Lukeman, M.; Wan, P. Photochem. Photobiol. 2006, 82, 50-56.

15. (a) Lukeman, M.; Veale, D.; Wan, P.; Munasinghe, V. R.; Corrie, J. E. T. Can. J. Chem. 2004, 82, 240-253; (b) Verga, D.; Nadai, M.; Doria, F.; Percivalle, C.; Di Antonio, M.; Palumbo, M.; Richter, S. N.; Freccero, M. J. Am. Chem. Soc. 2010, 132, 14625-14637.

16. Arumugam, S.; Popik, V. V. J. Am. Chem. Soc. 2009, 131, 11892-11899.

17. Kulikov, A.; Arumugam, S.; Popik, V. V. J. Org. Chem. 2008, 73, 7611-7615.

18. (a) Arumugam, S.; Popik, V. V. J. Am. Chem. Soc. 2011, 133, 15730-15736; (b) Arumugam, S.; Popik, V. V. J. Am. Chem. Soc. 2012, 134, 8408-8411. 
19. (a) Basarić, N.; Žabčić, I.; Mlinarić-Majerski, K.; Wan, P. J. Org. Chem. 2010, 75, 102-116;

(b) Basarić, N.; Cindro, N.; Bobinac, D.; Mlinarić-Majerski, K.; Uzelac, L.; Kralj, M.; Wan, P. Photochem. Photobiol. Sci. 2011, 10, 1910-1925; (c) Basarić, N.; Cindro, N.; Bobinac, D.; Mlinarić-Majerski, K.; Uzelac, L.; Kralj, M.; Wan, P. Photochem. Photobiol. Sci. 2012, 11, 381396; (d) Veljković, J.; Uzelac, L.; Molčanov, K.; Mlinarić-Majerski, K.; Kralj, M.; Wan, P.; Basarić, N. J. Org. Chem. 2012, 77, 4596-4610.

20. Doria, F.; Richter, S. N.; Nadai, M.; Colloredo-Mels, S.; Mella, M.; Palumbo, M.; Freccero, M. J. Med. Chem. 2007, 50, 6570-6579.

21. (a) Doria, F.; Nadai, M.; Folini, M.; Scalabrin, M.; Germani, L.; Sattin, G.; Mella, M.; Palumbo, M.; Zaffaroni, N.; Fabris, D.; Freccero, M.; Richter, S. N. Chemistry 2013, 19, 78-81;

(b) Doria, F.; Nadai, M.; Folini, M.; Di Antonio, M.; Germani, L.; Percivalle, C.; Sissi, C.; Zaffaroni, N.; Alcaro, S.; Artese, A.; Richter, S. N.; Freccero, M. Org. Biomol. Chem. 2012, 10, 2798-2806; (c) Nadai, M.; Doria, F.; Di Antonio, M.; Sattin, G.; Germani, L.; Percivalle, C.; Palumbo, M.; Richter, S. N.; Freccero, M. Biochimie 2011, 93, 1328-1340.

22. Rochlin, E.; Rappoport, Z. J. Org. Chem. 2003, 68, 216-226.

23. Albrecht, M.; Bohne, C.; Graznhan, A.; Ihmels, H.; Pace, T. C. S.; Schnurpfeil, A.; Waidelich, M.; Yihwa, C. J. Phys. Chem. A, 2007, 111, 1036-1044.

24. Montalti, M.; Credi, A.; Prodi, L.; Gandolfi, M. T. in Handbook of Photochemistry; CRC Taylor and Francis: Boca Raton, 2006.

25. Solntsev, K. M.; Huppert, D.; Agmon, N.; Tolbert, L. M. J. Phys. Chem. A 2000, 104, 46584669.

26. Kuhn, H. J.; Braslavsky, S. E.; Schmidt, R. Pure Appl. Chem. 2004, 76, 2105-2146. 
27. (a) Dixon, W. T.; Murphy, D. J. Chem. Soc. Faraday Trans. 2 1976, 72, 1221-1230; (b) Brodwell, F. G.; Cheng, J.-P. J. Am. Chem. Soc. 1991, 113, 1736-1743; (c) Gadosy, T. A.; Shukla, D.; Johnston, L. J. J. Phys. Chem. A 1999, 103, 8834-8839.

28. (a) Kleinman, M. H.; Flory, J. H.; Tomalia, D. A.; Turro, N. J. J. Phys. Chem. B 2000, 104, 11472-11479; (b) Pretali, L.; Doria, F.; Verga, D.; Profumo, A.; Freccero, M. J. Org. Chem. 2009, 74, 1034-1041.

29. (a) McClelland, R. A.; Chan, C.; Cozens, F. L.; Modro, A.; Steenken, S. Angew. Chem. Int. Ed., 1991, 30, 1337-1339; (b) Cozens, F. L.; Kanagasabapathy, V. M.; McClelland, R. A.; Steenken, S. Can. J. Chem., 1999, 77, 2069-2082.

30. (a) McClelland, R. A.; Banait, N.; Steenken, S. J. Am. Chem. Soc. 1986, 108, 7023-7027; (b) McClelland, R. A.; Kanagasabapathy, V. M.; Banait, N. S.; Steenken, S. J. Am. Chem. Soc. 1989, 111, 3966-3972.

31. Saha, K.; Lajis. N. H.; Abas, F.; Naji, N. A.; Hamzah, A. S.; Shaari, K., Aust. J. Chem. 2008, $61,821-825$.

32. (a) Goldstein S.; Rabani, J. J. Photochem. Photobiol. 2008, 193, 50-55; (b) Rahn, R. O. Photochem. Photobiol. 1997, 66, 450-455.

33. (a) Mossman, T. J. Immunol. Meth. 1983, 65, 55-63; (b) Boyd, M.R.; Kenneth, D.P. Drug. Dev. Res. 1995, 34, 91-109. 